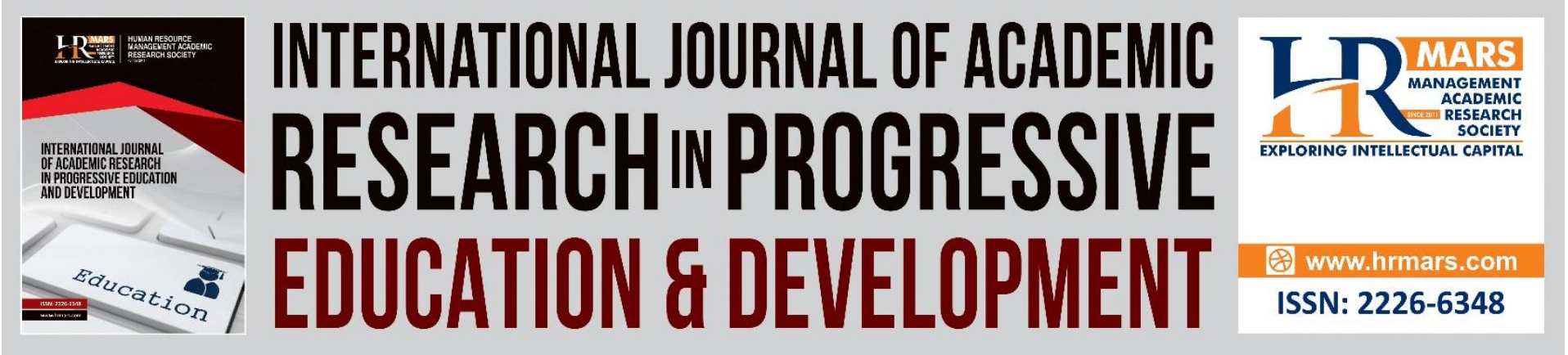

\title{
The Relationship between Students' Needs and Teaching Method of Teaching Arabic for Economic and Trade Negotiation at Yinchuan University of Energy
}

\author{
Kou Jie Ying, Suo Yan Mei, Saipolbarin bin Ramli \& Suo Yan Ju
}

To Link this Article: http://dx.doi.org/10.6007/IJARPED/v10-i3/10664 DOI:10.6007/IJARPED/v10-i3/10664

Received: 04 June 2021, Revised: 08 July 2021, Accepted: 24 July 2021

Published Online: 27 August 2021

In-Text Citation: (Ying et al., 2021)

To Cite this Article: Ying, K. J., Mei, S. Y., Ramli, S. bin, \& Ju, S. Y. (2021). The Relationship between Students' Needs and Teaching Method of Teaching Arabic for Economic and Trade Negotiation at Yinchuan University of Energy. International Journal of Academic Research in Progressive Education and Development, 10(3), 503-516.

Copyright: (c) 2021 The Author(s)

Published by Human Resource Management Academic Research Society (www.hrmars.com)

This article is published under the Creative Commons Attribution (CC BY 4.0) license. Anyone may reproduce, distribute, translate and create derivative works of this article (for both commercial and non-commercial purposes), subject to full attribution to the original publication and authors. The full terms of this license may be seen at: http://creativecommons.org/licences/by/4.0/legalcode

Vol. 10(3) 2021, Pg. 503 - 516

http://hrmars.com/index.php/pages/detail/IJARPED

JOURNAL HOMEPAGE

Full Terms \& Conditions of access and use can be found at http://hrmars.com/index.php/pages/detail/publication-ethics 


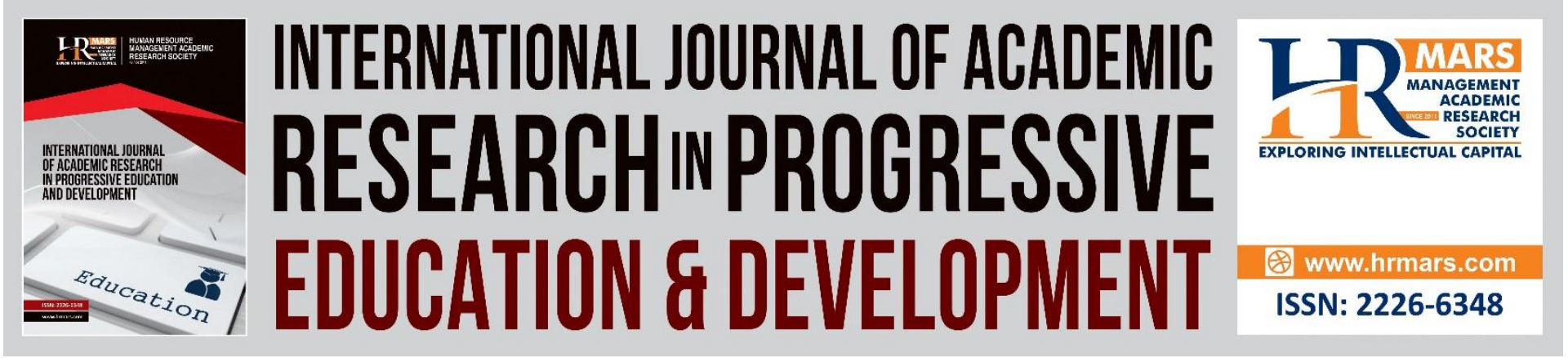

\title{
The Relationship between Students' Needs and Teaching Method of Teaching Arabic for Economic and Trade Negotiation at Yinchuan University of Energy
}

\author{
Kou Jie Ying ${ }^{1}$, Suo Yan Mei ${ }^{1}$, Saipolbarin bin Ramli ${ }^{1} \&$ Suo Yan \\ $\mathrm{Ju}^{2}$
}

${ }^{1}$ Faculty of Languages and Communication, Universiti Pendidikan Sultan Idris, 35900, Tanjong Malim, Perak, Malaysia, ${ }^{2}$ Faculty of Major Language Studies, Universiti Sains Islam, 71800, Nilai, Negeri Sembilan, Malaysia

Email: fatimahsuo@fbk.updi.edu.my/mys71fa@gmail.com

\begin{abstract}
The economic globalization and the implementation of the "One Belt and One Road" initiative directly reflected the urgent needs of Arabic language talents. As a result, many universities and colleges opened Arabic for economic and trade negotiations (AETN). This course aims to cultivate such interdisciplinary talents in the Arabic language. However, this research explored the relationship between students' needs and teaching methods which affected the teaching quality of the AETN. The study adopted a quantitative method and the data collected were analyzed through correlation by using the SPSS software. The research finding revealed that there were significant positive correlations between students' needs and teaching methods in the teaching of AETN $(r=.596, p<.01)$. The research will be a benefit for teachers and lecturers to adapt the teaching methods to improve the teaching quality of the AETN, and to promote the development of AETN teaching in Ningxia university of energy and train highlevel and high-quality Arabic professionals in Ningxia, China, As well as, this research could provide a valuable reference for AETN teaching for researches and universities to promote its further development.
\end{abstract}

Keywords: Students' Needs, Teaching Method, Arabic, Economic, Trade Negotiation

\section{Introduction}

The trend of economic globalization appears increasingly international communication and cooperation nowadays. With frequent and extensive China-Arab communication, many Arabic talents with excellent abilities in the Arabic language and comprehensive practical skills become an urgent need. To satisfy China's strategy and social needs, there are a lot of universities and colleges in China that have opened the Arabic for economic and trade negotiation (AETN) Purpose, and this course aims to cultivate such interdisciplinary talents of the Arabic language. However, AETN faces many problems: 1 . employers complained about a 
weakness for graduates' occupational skills (Xiu, 2017); 2. lecturers complained that the classroom atmosphere is not active and the students have less motivation to learn Arabic (Yin, 2014); 3. no lecturers had trained to be qualified as expertise for AETN, and Most of them still use traditional teaching method to teach AETN. Even some of the students got the job, but this method effect students' Arabic skills, and once they are in a real working situation, they cannot communicate with Arab well (Xiu, 2017). However, researchers believed that all the problems emerged because of ignoring learners' needs. Indeed, needs analysis is a method of obtaining a detailed description of language learners' needs by considering the learners' specific purpose, starting levels and target levels to be achieved. The results of needs analysis usually serve as primary evidence for LSP teaching (Hutchinson-Waters, 1987). Without thorough needs analysis, it is impossible to carry out effective foreign language teaching and achieve expected teaching goals (Shu, 2004). Although many researchers studied English for a specific purpose and there are some researches focused on Arabic for specific purposes, only a few researches mentioned AETN and none of them explored the relationship between students' needs and teaching methods in AETN in Ningxia, China. Therefore, this research filled up the gap in this field.

The objective of this research was to explore the relationship between students' needs and teaching methods that affected the teaching quality of the AETN in Yinchuan University of energy, Ningxia, China and put forward some suggestions to promote the development of AETN teaching at Ningxia university of energy and train high-level and high-quality Arabic professionals in Ningxia, China. As well as, this research could provide a beneficial reference for AETN teaching for researchers and universities to promote its further development.

\section{Literature Review}

Arabic for the Economic and Trade Negotiation course is an applied science based on economics, psychology, logic, management, and other disciplines and a comprehensive course introducing the content and methods of business negotiations in commodity trade and economic cooperation. Arabic course for Economic and Trade Negotiation is not only a science but also an art. It took international and domestic business negotiation as the object, based on relevant laws and regulations, and combined for science and technology, economic management, finance, human geography, social psychology, commodity and trade, and other disciplines. It has characteristics of a wide range of knowledge, strong legal, practical, and strategic (Xiu, 2017; Xiao, Yang and Jiang, 2009).

\section{Need Analysis}

Every language for a specific purpose course, regardless of language or purpose, begins with the recognition that the course reflects some kinds of needs. This may be a need on the part of the learners, the community, the language program itself, the university, international trends, or any number of other factors. While any kind of learning, needs, and specific purposes go hand in hand, historically, the notion of needs analysis or needs assessment in education has been linked with the very beginnings of LSP (Halliday, Mclntosh, \& Strevens, 1964). Robinson (1991) mentioned an effective ESP course develops from needs analysis that "aims to specify as closely as possible what exactly it is that students have to do through the medium of English," so the role of demand analysis in ESP has become irreplaceable. Along with developing a learner-centered approach, it was introduced in the teaching of general English to learn about student's requirements and identify problems in language teaching; 
needs analysis has become the cornerstone of ESP and makes ESP teaching content compact (Brindley, 2001, Cowling, 2007). Richards (1984) declared that needs analysis is comprised of the learner's requirements for language learning. The learner organizes the schedule of learning needs according to the degree of his needs. Berwick (1989) pointed out that needs analysis can guide students' present learning goals and future career goals. Brown (1995) pointed out that needs analysis was "the activities involved in gathering information that will serve as the basis for developing a curriculum that will meet the learning needs of a particular group of learners". Brown (1995) also illustrates his opinion that needs analysis is to develop an appropriate curriculum that can satisfy the learning needs of a particular group of students through collecting relevant information. So, needs analysis aims are to grasp what the learners already know and what they need to know, then the gap between two aspects can be bridged by the course.

\section{Teaching Methods}

In teaching and learning, student's ability, and readiness to learn not only to depend on the student themselves but also lie in the suitability of a teacher's teaching method (Felder \& Henrique, 1995). Grasha and Hicks (2000) argued that to guarantee the effectiveness of a teaching and learning process, it is simply not enough to focus only on the students' learning styles. Teaching methods also need to be considered as an essential element in a class. According to Ayeni (2011), teaching is a continuous process that involves bringing about desirable changes in learners with appropriate methods. Adunola (2011) indicated that to bring desirable changes in students, teaching methods used by educators should be best for the subject matter. In the study, teaching methods as the independent variable to explore the relationship with the students' needs that affect the AETN course teaching quality in the Yinchuan University of Energy.

According to Wright (1987), one teaching method involves a complex mix of beliefs, attitudes, strategies, techniques, motivation, personality, and control. The teachers teaching styles can be seen when they conduct the teaching and learning process. The teaching method is determined by personal qualities and attitudes. Grasha (1996) indicated that teaching methods represent the pattern of teachers' needs, beliefs, and behavior shown by teachers in the classroom. Richards and Rodgers (2001) defined a teaching method as "a systematic set of teaching practices based on a particular theory of language and language learning".

\section{The Relationship between Teaching Methods and Students Needs}

Previous researchers found that there were a meaningful relationship and positive direction between teaching methods and students' needs in the field of education and teaching and the motivation and the results of the students improve. Iurea, Neacşu, Safta \& Suditu (2011) indicated that the relation between the teaching methods and learning styles impacts the students' academic conduct". Ghani, Daud, and Sahrir (2016) examined the efficacy of using websites to learn the Arabic language for tourism purposes at the general studies department, MARA Poly Tech College (KPTM), Malaysia. The study concluded that using the internet and websites is an effective way to teach the Arabic language for tourism purposes through providing good, proactive support and authentic learning materials for students and teachers. Zhorik (1990) also found that teachers' teaching style was influenced by the ideology and beliefs of students and knowledge. Felder \& Henriques (1995) studied 
that a teaching style that parallels students' learning styles will improve learning, attitudes, behavior, and motivation.

Studies applied the situational language teaching method in business English course (Yu, 2013) showed that situational language teaching method can 1 active the classroom atmosphere; 2 improve teaching quality; 3 simulate the language learning environment to form a language communication atmosphere; 4 improve the initiative of students learning ability; 5 shorten the distance between the learning environment and the work environment. Hence, the situational language teaching method applied in ESP courses is very necessary and should encourage lecturers to use it (Wang, 2015; Zhao, 2014, Yu, 2013, \& Tan, 2010). The other authors adopted the project-based learning method teaching in the travel English course, hotel English course, and English for service outsourcing course, teaching Arabic for the cultural purpose (Zen \& Jiang, 2010; Gao, 2015 \& Sun, 2014). The result proved the project-based learning method can 1 mobilize the internal learning motivation of students'; 2 develop students' various abilities; 3 effectively stimulate the creative thinking of teachers and it is a teaching strategy (Yang, 2018; Zen \& Jiang, 2010; Yu, 2016; Gao, 2015; Zhang, 2017; Gao, 2014; Jamous \& Chik, 2012; Li, Chen \& Li, 2014).

Results of these studies provided good guidance and reference value and support of the hypothesis of the present research that the teaching methods and students' needs have a significant relationship and positive direction in the AETN course. These studies also contributed to setting up a guidebook for this study that could help the researchers to understand students' particular learning needs, grouped according to their dominant learning style, and to develop alteration of the teaching method according to these data.

\section{Research Methodology \\ Population and Sample}

This research covered the students who are majoring in the Arabic language at Yinchuan university of energy, Ningxia, China, and only 60 students purposefully choose from a total of 110 students who are majoring in the Arabic language. Those samples from year four were involved in this research. The reason for choosing year four students is because they had already spent three years studying the Arabic language and one year focusing on studying AETN and they were more self-confident and more representative of the university's AETN level.

\section{Instrument}

This research adopted the quantitative method by the SPSS as an instrument for data collection and analysis. Robinson (1991) suggested techniques for conducting needs analysis, including questionnaires, interviews, and case studies. Dudley-Evans and St. John (1998) considered texts, questionnaires, and structured interviews to be among the main sources for needs analysis. The researcher used the questionnaire survey contained 7-point Likert-type scales. The questionnaire consists of two parts with 15 questions. Part A consisted of respondents' information such as gender, age, and program; part B consisted of the background of respondents' Arabic learning and part $C$ were questions relevant to teaching methods. Survey instruments were based on 7-point Likert scales and were from Very Strongly Agree to Very Strongly Disagree. 


\section{Procedure}

The survey questionnaire was sent to the lecturer who is teaching AETN at Yinchuan university of energy. The Lecturer distributed the questionnaire online to the participants to complete the survey questionnaire by the assigned deadline. The recovery ratios were much than $99 \%$ of participants.

\section{Research Method}

This research depended on the survey research design. The descriptive method used for Category frequencies of the demographic variables which were gender, age, year, period of Arabic study before entering the university, and level of interest in learning Arabic for the sample of 60 undergraduate final year students from Yinchuan university of energy, Ning Xia, China. The correlation method will apply to determine the relationship between two variables of students' needs and teaching method in teaching AETN. The main advantage of using the correlation method is that it simply determines the relationship between two variables, whether it is a positive or negative relationship or no relationship (Jennifer, 2015).

\section{Findings and Discussing Descriptive Analysis}

The respondents' information in this study was gender, age, year, year of Arabic study before entering the university, and level of interest in learning Arabic. The total number of respondents used for the final analysis was 60 . Table 1.1 showed that the number of male participants in the study was $23(38.3 \%)$ and female was $37(61.7 \%)$. This indicated that female respondents were more than males in the survey. And the analysis showed that the age group between $15-20$ years $(\mathrm{N}=4,6.7 \%)$ was in the distribution. Then, the Age group between 21 $25 y$ rs was ( $N=56,93.3 \%)$ in the analysis. About the year of the participants' study, the analysis indicated that $100 \%$ of them were final-year students since this research focused on students who are studying Arabic for a specific purpose which is only offered for final year students. However, the number of students who study the Arabic language before entering the university within 0-6 months was ( $N=44,73.3 \%)$. Again, the analysis found that the students who study Arabic before they were entering the university within $0.5-1$ years were $(\mathrm{N}=16$, 26.7\%). It is understandable from this analysis that students who study Arabic 0-6 months before they were entering the university more than students who study Arabic within 0.5-1 years in the survey and from the point of interest in Learning Arabic, students who have interested in learning Arabic were ( $\mathrm{N}=32,53.3 \%)$, normal in learning Arabic were $(\mathrm{N}=13$, $21.7 \%)$ and not interested in learning Arabic were ( $N=15,25.0 \%)$. The analysis found that most students have enthusiasm and expectation for learning Arabic. At the same time, it is a good start for further studying AETN. 
INTERNATIONAL JOURNAL OF ACADEMIC RESEARCH IN PROGRESSIVE EDUCATION AND

DEVELOPMENT

Vol. 10, No. 3, 2021, E-ISSN: 2226-6348 @ 2021 HRMARS

Table 1: Distribution of Respondents according to student's Background Characteristics

\begin{tabular}{|c|c|c|c|}
\hline & Characteristics & $\underline{\mathbf{N}}$ & $\%$ \\
\hline \multirow[t]{2}{*}{ Gender } & Male & 23 & 38.3 \\
\hline & Female & 37 & 61.7 \\
\hline \multirow[t]{2}{*}{ Age } & $15-20$ years & 4 & 6.7 \\
\hline & $21-25$ years & 56 & 93.3 \\
\hline Years of study & Final year & 60 & 100.0 \\
\hline \multirow[t]{2}{*}{ Periods of Study Arabic } & $0-6$ months & 44 & 73.3 \\
\hline & 0.5 -1years & 16 & 26.7 \\
\hline \multirow{3}{*}{$\begin{array}{l}\text { Interested in learning } \\
\text { Arabic }\end{array}$} & Interested & 32 & 53.3 \\
\hline & Normal & 13 & 21.7 \\
\hline & Not interested & 15 & 25 \\
\hline Total & & 60 & 100 \\
\hline
\end{tabular}

\section{Reliability Test}

A reliability test is a necessary but not sufficient condition for validity. It means that if you want validity, you must have reliability (Nunnally\&Bernstein,1994). Reliability is the assessment of measurement errors within the constructs of an instrument. Researchers can use categories of reliability researchers can use (Split-half, Gutman, Strict parallel) to assess reliability. This study used Cronbach Alpha and the reliability coefficient is used to check variables' consistency degree of each measurement item in the questionnaire.

There is no consensus among researchers on the acceptable threshold levels for Cronbach's alpha. However, Devellis indicated that if the variable is considered to have good reliability, the acceptable alpha values range must be greater than 0.7 (DeVellis, 2003) and the researchers adopted the DeVellis (2003) points. There are two variables in the research, the student's needs, and the teaching method. It analyzes the reliability of each variable and measurement results shown in table 2 : 
INTERNATIONAL JOURNAL OF ACADEMIC RESEARCH IN PROGRESSIVE EDUCATION AND DEVELOPMENT

Vol. 10, No. 3, 2021, E-ISSN: 2226-6348 @ 2021 HRMARS

Table 2: Reliability Analysis of all constructs

\begin{tabular}{|c|c|c|c|c|}
\hline Factor & Item & $\begin{array}{l}\text { Corrected } \\
\text { Item-Total } \\
\text { Correlation }\end{array}$ & $\begin{array}{l}\text { Cronbach's } \\
\text { Alpha if Item } \\
\text { Deleted }\end{array}$ & $\begin{array}{l}\text { Cronbach's } \\
\text { Alpha }\end{array}$ \\
\hline \multirow{10}{*}{$\begin{array}{l}\text { teaching } \\
\text { method } \\
\text { (A) }\end{array}$} & $\begin{array}{l}\text { I am satisfied with the } \\
\text { teaching method in AETN }\end{array}$ & 0.868 & 0.953 & \multirow{10}{*}{0.959} \\
\hline & $\begin{array}{l}\text { Lecturers adjust the } \\
\text { teaching method } \\
\text { according to the } \\
\text { students' needs }\end{array}$ & 0.746 & 0.958 & \\
\hline & $\begin{array}{l}\text { The lecturer teaches } \\
\text { AETN by student- } \\
\text { centered approach } \\
\text { (students discuss in } \\
\text { groups; students } \\
\text { speaking and lecturer } \\
\text { commenting in the class } \\
\text { etc.) }\end{array}$ & 0.853 & 0.953 & \\
\hline & $\begin{array}{l}\text { The lecturer teaches } \\
\text { AETN by teacher-led } \\
\text { teaching model } \\
\text { (grammar-translation } \\
\text { method; direct method, } \\
\text { etc.) }\end{array}$ & 0.74 & 0.958 & \\
\hline & $\begin{array}{l}\text { The teaching method } \\
\text { that used in AETN } \\
\text { improve my learning } \\
\text { efficiency }\end{array}$ & 0.854 & 0.953 & \\
\hline & $\begin{array}{l}\text { Lecturer adopts } \\
\text { blackboard+chalk means } \\
\text { in teaching AETN }\end{array}$ & 0.76 & 0.957 & \\
\hline & $\begin{array}{l}\text { Lecturer adopts modern } \\
\text { means in teaching AETN } \\
\text { (network, mobile phone, } \\
\text { teaching platform, etc.) }\end{array}$ & 0.874 & 0.952 & \\
\hline & $\begin{array}{l}\text { Lecturer adopts manifold } \\
\text { comprehensive means in } \\
\text { teaching AETN }\end{array}$ & 0.832 & 0.954 & \\
\hline & $\begin{array}{l}\text { AETN class atmosphere is } \\
\text { perfect and I will speak } \\
\text { actively in the class }\end{array}$ & 0.837 & 0.954 & \\
\hline & $\begin{array}{l}\text { The AETN teaching is } \\
\text { interesting and attractive } \\
\text { and it can stimulate my } \\
\text { interest in learning }\end{array}$ & 0.827 & 0.954 & \\
\hline
\end{tabular}




\begin{tabular}{|c|c|c|c|c|}
\hline \multirow[t]{10}{*}{$\begin{array}{l}\text { Students' } \\
\text { needs (S) }\end{array}$} & $\begin{array}{l}\text { Offering the AETN is very } \\
\text { necessary }\end{array}$ & 0.834 & 0.932 & \multirow{10}{*}{0.941} \\
\hline & $\begin{array}{l}\text { AETN is very practical and } \\
\text { will use in the future } \\
\text { work }\end{array}$ & 0.747 & 0.936 & \\
\hline & $\begin{array}{l}\text { To pass the various } \\
\text { related exams in the } \\
\text { university or in society } \\
\text { after learning AETN }\end{array}$ & 0.792 & 0.934 & \\
\hline & $\begin{array}{l}\text { To earn credit and get a } \\
\text { degree after learning } \\
\text { AETN }\end{array}$ & 0.731 & 0.937 & \\
\hline & $\begin{array}{lr}\text { To } & \text { improve } \\
\text { comprehensive language } \\
\text { application } \\
\text { (listening, ability } \\
\text { reading, and writing) } \\
\text { after learning AETN }\end{array}$ & 0.761 & 0.935 & \\
\hline & $\begin{array}{l}\text { To learn some } \\
\text { professional knowledge } \\
\text { of business negotiation } \\
\text { after learning AETN } \\
\end{array}$ & 0.707 & 0.938 & \\
\hline & $\begin{array}{l}\text { To better understand and } \\
\text { appreciate the Arab } \\
\text { business culture after } \\
\text { learning AETN }\end{array}$ & 0.742 & 0.936 & \\
\hline & $\begin{array}{l}\text { To improve interpersonal } \\
\text { communication skills } \\
\text { after learning AETN }\end{array}$ & 0.714 & 0.938 & \\
\hline & $\begin{array}{l}\text { I really enjoyed taking } \\
\text { AETN classes }\end{array}$ & 0.866 & 0.93 & \\
\hline & $\begin{array}{l}\text { To learning AETN that } \\
\text { achieve my aims and } \\
\text { objectives }\end{array}$ & 0.711 & 0.938 & \\
\hline
\end{tabular}

The results showed that the Cronbach alpha for A and S are 0.959 and 0.941 and means that all the constructs were measured correctly going by their Cronbach's alpha values that ranged greater than 0.7 . It showed that variables have good internal consistency reliability. CITC is greater than 0.5 standards indicated that the measurement items meet the research requirements. Seeing the data of Cronbach's Alpha if Item Deleted, Cronbach's Alpha did not increase when either question was deleted. This showed that all the constructs have good reliability. This further indicated that the result could be used for further analysis.

\section{Validity Test}

Cohen \& Cohen (1983) argued that different ways could be used to measure validity. It 
DEVELOPMENT

Vol. 10, No. 3, 2021, E-ISSN: 2226-6348 @ 2021 HRMARS

included: content validity, criterion-related validity, construct validity, systemic validity, and face validity. The present research, it used content validity and structure validity for measuring.

\section{Content Validity}

The questionnaire used in this study is based on a literature review to show the relationship or association construction between variables. Researchers modified some items and added some latest items in the questionnaire, so the questionnaire will be provided to three professors who are from the Arabic department of three different universities for checking purpose and seek their valuable opinion to ensure it covers all the variables being measured as a way of eliminating content validity. After receiving their written feedback, the researchers revised the instrument and sent it again to professors for a second review. After analyzing the qualitative data, the research result was sent to the interviewees and sought their attention. If they agree that their opinions and experiences reflected the research result. Therefore, it can be considered that the scale has the content validity that met the requirements.

\section{Structure Validity}

\section{Validity Test for the Dependent Variable}

SPSS version 22 is used for exploratory factor analysis to carry on the Kaiser-Meyer-Olkin (KMO) and Bartlett test of Sphericity on the scale. Table 3 showed the Kaiser-Meyer-Olkin (KMO) value was .828, exceeding the recommended value of 0.6 (Kaiser, 1974). Then, Bartlett's Test of Sphericity (Sig.<0.001) reached statistical significance (Barlett, 1954; Hair, Black, Babin \& Anderson,2010) and indicated the questionnaire data to factor the prerequisites.

Table 3: KMO and Bartlett's Test

\begin{tabular}{|l|l|l|}
\hline \multicolumn{2}{|l|}{ Kaiser-Meyer-Olkin Measure of Sampling Adequacy } & $\mathbf{0 . 8 2 8}$ \\
\hline \multirow{3}{*}{ Bartlett's Test of Sphericity } & Approx. Chi-Square & 2326.835 \\
\cline { 2 - 3 } & df & 780 \\
\cline { 2 - 3 } & Sig. & .000 \\
\hline
\end{tabular}

Therefore, further analysis is carried out. Principal component analysis (PCA) was used to extract the factor and the characteristic root is greater than 1 as a factor to extracting the common factor. Factor rotation used the Varimax Orthogonal Rotation to perform factor analysis. The analysis results showed in table 4 below:

\section{The Result of Correlation between Students' Needs and Teaching Methods in Teaching AETN}

The analysis was conducted on the relationship between students' needs and teaching methods in AETN in Yinchuan University of Energy, Ningxia, China. Researchers used Pearson product-moment correlation coefficient. Preliminary analyses were performed to ensure the data was free from missing data. Analysis results showed a significant positive correlation ship between $S$ and A in AETN $(r=.596, p<.01)$. The research further concluded teaching methods must be considered for students' needs. It should emphasize the principal status of students and based on students' needs that to reflect students' central position. 
Table 7: Correlation Analysis

\begin{tabular}{|l|l|l|l|}
\hline & & $\begin{array}{l}\text { Students' needs in } \\
\text { AETN }\end{array}$ & Hypothesis \\
\hline Teaching method & Pearson Correlation & .596 & \\
\hline & Sig. (2-tailed) & .000 & H1 \\
\hline & $\mathrm{N}$ & 60 & supported \\
\hline
\end{tabular}

\section{Conclusion and Recommendation}

Due to the trend of economic globalization and the "One Belt and One Road" initiative, appeared increasingly international communication and cooperation. China and Arab countries have a good relationship. Meanwhile, the Arab region is an important convergence zone of China's "One Belt and One Road" initiative. So, strengthening the cooperation with Arab countries is an important part of China's diplomatic strategy. It led to the need for many Arabic interdisciplinary talents who was having an excellent ability of Arabic language and comprehensive practical skills urgently. Therefore, teaching Arabic for economic and trade negotiation in China is a big gap which is none of the researchers did research about it before. Although some of the universities offered to teach Arabic for economic and trade negotiation, there are many problems. According to the result of this research, Yinchuan University makes an excellent example of this file. Teaching Arabic for economic and trade negotiation has fulfilled the need of students based on the meaningful relationship between students' needs and teaching methods in teaching Arabic for economic and trade negotiation. Based on the result of this research, there are some recommendations as a following:

\section{Flexible use of Diverse Teaching Methods}

In Yinchuan university of energy, the teaching Arabic for economic and trade negotiation course adopted the traditional teaching method (Grammar translation). However, there is no difference from the other course. Indeed, the best teaching is the unity of teaching and learning. Therefore, the ideal teaching method is the flexible use of diversified teaching methods to achieve the goal of education. Overall, according to the data analysis between A and $S$, from the aspects of changing the teaching content and methods, students' needs as the starting point and students as the principle of the AETN teaching and the lecturers only serves as the guide stimulate students' interest and motivation in learning AETN and restore the original intention of offering the AETN.

\section{Using Modern Educational Techniques}

In Yinchuan university of energy, Ningxia, China, lecturers rarely used multimedia to assist the AETN teaching, which is one of the reasons for the boring and single of the AETN teaching and affected the teaching quality. Therefore, it should use modern teaching facilities. Indeed, it can break through the teaching key and difficult points and make the teaching method more convenient, fast, and efficient. It also can fundamentally change the traditional and monotonous teaching method and activate students' thinking and stimulate students' interest in learning AETN. Although multimedia instruction is the product of the development of educational information technology, from the practical point of view, it only plays a supplementary role and service for teaching AETN. To correctly view the use of multimedia equipment in teaching, to scientific and reasonable use. Therefore, Multimedia equipment should be used correctly in the AETN teaching, neither let it become a furnishing nor over 
DEVELOPMENT

Vol. 10, No. 3, 2021, E-ISSN: 2226-6348 @ 2021 HRMARS

enlarge its role and should be used scientifically and rationally.

\section{Research Contribution}

Need analysis and teaching method for teaching Arabic for Nonnative speakers is discussed by many researchers in the world, but unfortunately, many language educators did not realize those teaching languages must fulfill the need of students, as well as its relationship with the teaching method. Therefore, this research will benefit Arabic lectures and educators not only in China but also all the world to the development of AETN teaching and useful to train highlevel and high-quality Arabic professionals, besides that, the research could provide a beneficial reference for AETN teaching for researchers and universities to promote its further development.

\section{Reference}

Adunola, O. (2011). The Impact of Teachers' Teaching Methods on the Academic Performance of Primary School Pupils in Ijebu-Ode Local cut Area of Ogun State. Ego Booster Books, Ogun State, Nigeria.

Ayeni, A. J. (2011). Teachers' professional development and quality assurance in Nigerian Secondary Schools. World Journal of Education, 1(2):143-149.

Bartlett, M. S. (1954). A note on the multiplying factors for various chi square approximations. Journal of the Royal Statistical Society 16(2), 296-298.

Berwick, R. (1989). Needs assessment in language programming: From theory to practice. Cambridge: Cambridge University Press.

Brindley, G. (2001). Outcomes-based assessment in practice: Some examples and emerging insights. Language Testing, 18(4), 393-407.

Brown, J. D. (1995). The Elements of Language Curriculum: A Systematic Approach to Programma Development. Boston: Heinle \& Heinle.

Jennifer, C. (2015). Pearson's Product-Moment Correlation: Sample Analysis.

Cohen, J., \& Cohen, P. (1983). Applied multiple regression/correlation analysis for the behavioral sciences. Hillsdale, NJ: Erlbaum.

Cowling, J. D. (2007). Needs analysis: Planning a syllabus for a series of intensive workplace courses at a leading Japanese company, English for Specific Purposes (26), 426-442.

DeVellis, R. F. (2003). Scale Development: Theory and Application. California: Sage Publications, Inc.

Dudley- Evans T., \& John, M. J. (1998) Developments in ESP [M]. Cambridge: Cambridge University Press.

Jiang, K. Y. (2014). Training modes of comprehensive Arabic talents in Ningxia higher learning institutions in time of information. Northwest University for Nationalities (Philosophy and Social Science), 5,165-169

Halliday, M. A. K., McIntosh, A., \& Strevens, P. (1964). The Linguistic Sciences and Language Teaching. London: Longmans, Pp. xix +322.

Hair, J. F., Black, W. C., Babin, B. J., \& Anderson, R. E. (2010). Multivariate data analysis: A global perspective. Upper Saddle River, NJ: Pearson.

Hutchinson, T., \& Waters. (1987) A. English for a specific purpose [M]. Cambridge: Cambridge University Press, 18-19.

Kaiser, H. F. (1974). An index of factorial simplicity. Psychometrika, 39(1), 31-36.

Nunnally, J. C., \& Bemstein, L.H. (1994). Psychometric theory. New York, NY: McGraw-Hill. 
Li, X., Chen, P., \& Li, K. (2014). Application of project-based language teaching method in ESP course in higher vocational Colleges. Read and Write Periodical, 11(8),31-32

Lurea, C., Neacşu, L., Safta, C. G., \& Suditu, M. (2011). The Study of the Relation between the Teaching Methods and the Learning Styles - The Impact upon the Students' Academic Conduct. Procedia Social and Behavioral Sciences 11,256-260

Robinson, P. C. (1991). ESP today: A practitioner's Guide. United Kingdom: Prentice-Hall International Ltd.

Richards, J. C. (1984). The secret life of methods. TESOL Quarterly, (18), 7-23.

Richards, J., \& Rodgers, T. (2001). Approaches and Methods in Language Teaching. New York: Cambridge University Press.

Gao, R. J. (2015). Implementation of project-based language teaching method in ESP coursetaking hotel English course of hotel management major in higher vocational colleges as an example. Teaching Exploration, 98-99

Ghani, M. T. A., Daud, W. A. A. W., \& Sahrir, M. S. (2016). The Effectiveness of Using Website in Learning Arabic Language for The Purpose of Tourism: A Case Study among Students at College Poly-Tech MARA (KPTM). Singapore: Springer Science+Business Media

Grasha, A. F., \& Hicks, N. Y. (2000). Integrating teaching styles and learning styles with instructional technology. College Teaching, 48 (1), 2- 15.

Grasha, A. F. (1996). Teaching with Style: A Practical Guide to Enhancing Learning by Understanding Teaching and Learning Styles. Pittsburgh, PA: Alliance Publishers.

Felder, R. M. \& Henriques, E. R. (1995) Learning and teaching styles in foreign and second language education. Foreign Language Annals, 28 (1), 21-31.

Jamous, R., \& Chik, A. R. (2012). Teaching Arabic for Cultural Purposes: A Case Study of Francophone Program of Arabic at Aleppo University. Social and Behavioral Sciences 66, $37-45$.

Shu, D. F. (2004). Teaching Reform of Foreign Language [M]. Shanghai Foreign Language Education Press, Shang Hai.

Tan, J. (2010). Optimizing business English listening and speaking course in higher vocational colleges with the content-based instruction teaching method. Journal of Hu Bei TV University, 30(9), 39

Xiu, R. (2017). Teaching Reform of Arabic Course for Economic and Trade Negotiation [J]. Quality Education in Western China (4): 67-68.

Yang, L. J. (2018). Application of project-based language teaching method in ESP courses. Journal of Henan College of Finance\&Taxation, 32(5), 87-90

$\mathrm{Yu}, \mathrm{H}$. B. (2013). Content-based instruction teaching method: the reformation of business English teaching in higher vocational colleges. Journal of Jilin Radio and TV University, 5,38-39

Sun, G. F. (2014). Application of project-based language teaching method in ESP courses of vocational colleges-taking outsourcing English as an example. Journal of Jiangxi Vocational and Technical College of Electricity, 27(2), 52-55

Wright, T. (1987). Roles of teachers and Learners. United Kingdom: Oxford University Press

Wang, L. Y. (2015). On the Application of content-based instruction teaching approach in higher vocational ESP teaching. Journal of Liaoning Administrators College of Police and Justice, 124-126

Zahorik, J. A. (1990). Stability and flexibility in teaching. Teacher and Teaching Education, 6 (1),69-80. 
INTERNATIONAL JOURNAL OF ACADEMIC RESEARCH IN PROGRESSIVE EDUCATION AND DEVELOPMENT

Vol. 10, No. 3, 2021, E-ISSN: 2226-6348 @ 2021 HRMARS

Zhao, X. N. (2014). Application of content-based instruction teaching method in business English teaching. Journal of Educational Institute of Jilin Province, 30(4), 15-16.

Zen, L. H., \& Jiang, Y. (2010). Application of project-based language teaching method in ESP course -take tourism English course of tourism management major in higher vocational education as an example. Professional Teaching Research, 6,124-125. 